\title{
REDUCED DOSE OF ORMELOXIFENE IN DYSFUNCITONAL UTERINE BLEEDING-SAFETY AND EFFECTIVENESS
}

\author{
Suhasini $K^{1}$, Lakshmi $G^{2}$, Padma $Y^{3}$, Sabitha $C^{4}$ \\ ${ }^{1}$ Associate Professor, Department of Obstetrics \& Gynaecology, Kakatiya Medical College, Warangal. \\ ${ }^{2}$ Associate Professor, Department of Obstetrics \& Gynaecology, Kakatiya Medical College, Warangal. \\ ${ }_{3}^{3}$ Associate Professor, Department of Obstetrics \& Gynaecology, Kakatiya Medical College, Warangal. \\ ${ }^{4}$ Post Graduate, Department of Obstetrics \& Gynaecology, Kakatiya Medical College, Warangal.
}

\begin{abstract}
AIM OF THE STUDY

To evaluate the effectiveness and safety of reduced dose of Ormeloxifene in the management of Dysfunctional Uterine Bleeding (DUB). Long term medical management for DUB, which is ideal and cost-effective is not yet available. Once it is available, it can revolutionise the management of DUB in developing countries. If Ormeloxifene is proved to be effective long-term at lower doses with minimal side effects, it can prevent the major number of blood transfusions and hysterectomies, which are common especially in the lower socioeconomic group of patients who cannot afford costly conservative measures.
\end{abstract}

\section{MATERIAL AND METHODS}

Out of 240 eligible patients with DUB, recruited from Gynaec OPD of CKM Hospital, Warangal, only 160 women consented to participate, out of which half of the patients were given the standard dose of Ormeloxifene that is $60 \mathrm{mg}$ twice a week for 3 months and once a week for 3 months (Group A). Half of the patients were given reduced dose of Ormeloxifene that is $30 \mathrm{mg}$ twice a week for all 6 months (Group B); 54 women from each group who completed the 6 months treatment and came regularly for followup were included in the present study. Both groups were matched for age and parity.

Pre-treatment PBAC (Pictorial Blood Loss Assessment Chart) scores were done for all cases and mean PBAC scores were calculated. Same was done at follow-up visits at 1 month, 3 months and 6 months. Side effects were looked for and TVS was done for Endometrial Thickness (ET)/Ovarian cysts. Haemoglobin estimation was done at the end of the study. Effectiveness was taken as reduction of mean PBAC score at the end of 6 months.

\section{CONCLUSION}

Mean PBAC scores at the end of 6 months, in each group showed a reduction of $86.64 \%$ of blood loss in group A (standard dose of Ormeloxifene) and $87.69 \%$ of blood loss in group B (reduced dose of Ormeloxifene). The reduction in both groups was similar. When the reduction in group $A$ and group $B$ was compared, the difference was not statistically significant $[\mathrm{P}=0.33]$. Hence, the lower dose schedule followed in group B can be recommended for management of DUB. This could make long term usage of Ormeloxifene more feasible when proved safe by larger randomised double blind studies.

\section{KEYWORDS}

DUB, Ormeloxifene, SERMs, PBAC Score.

HOW TO CITE THIS ARTICLE: Suhasini K, Lakshmi G, Padma Y, et al. Reduced dose of ormeloxifene in dysfunctional uterine bleeding-safety and effectiveness. J. Evolution Med. Dent. Sci. 2016;5(14):664-669, DOI: 10.14260/jemds/2016/152

\section{INTRODUCTION}

Conservative methods for long term management of menorrhagia developed over the past many years like endometrial ablation by different methods, anti-fibrinolytic agents (Tranexamic acid), non-steroidal anti-inflammatory agents (Mefenamic acid) and Levonorgestrel releasing intrauterine device has given a lot of options to women suffering from DUB. ${ }^{1}$ Progesterones, Danazol and GnRh analogs are also available, but unfortunately all these modalities are costly and most of the women in developing countries cannot afford them especially long term. ${ }^{2}$

Financial or Other, Competing Interest: None.

Submission 01-01-2016, Peer Review 30-01-2016,

Acceptance 03-02-2016, Published 18-02-2016.

Corresponding Author:

Dr. Suhasini K,

H. No. 6-3-855/10/A,

Ameerpet, Hyderabad-500016, Telangana.

E-mail: kambhamsuhasini@gmail.com

DOI: $10.14260 /$ jemds $/ 2016 / 152$
In the past few years with the advent of Ormeloxifene, which can be afforded by the under privileged also, there is good hope for conservative management of menorrhagia without surgical intervention in developing countries like India. Ormeloxifene was first introduced in India in 1991 as a contraceptive-Saheli. It was actually launched by CDR Institute of Lucknow in 1991. There are no studies of Ormeloxifene in USA and UK and it is not approved in those countries yet. It was approved by FDA in India in 1992. It was later incorporated in family welfare program of India in 1995. It is also known as Centchroman.

Several studies in the past, have shown the efficacy of Ormeloxifene in the management of DUB. The advantages of Ormeloxifene are its efficacy, only minor side effects, patient compliance and cost effectiveness. ${ }^{3,4}$ Ormeloxifene does not have serious side effects like venous thromboembolism, which is one of the major side effects when DUB is treated with hormones. 
However, there are concerns about occurrence of ovarian cysts and endometrial hyperplasia with Ormeloxifene. ${ }^{5}$

The long term safety of Ormeloxifene used for more than 1 to 2 years is yet to be proved. Since side effects could be dose related, we have attempted lowering the standard dose recommended and studied the efficacy and side effects with a lowered dose schedule.

Incidence of women seeking help for menorrhagia is about 20 to $30 \%$ in 35 to 50 years of age group. ${ }^{6}$ Menorrhagia causes disability due to severe anemia and its consequences. Many times blood transfusions are needed and we all know its risks and complications. DUB also leads to anxiety and stress which can lead to both physical, emotional and socioeconomical problems. ${ }^{7}$

Ormeloxifene was found to be more effective than progesterogens in the management of menorrhagia.8,9 Progesterogens are ineffective in the treatment of ovulatory DUB. 10

Ormeloxifene is a good option in DUB, because it is a SERM (Selective Estrogen Receptor Modulator) which acts as an estrogen antagonist on uterus and breast, but acts as a mild agonist on vagina, bone, central nervous system and serum lipids.11,12 and its beneficial effects makes it even more preferable. There is relief from dysmenorrhea in most patients treated with Ormeloxifene. It also maintains cognitive function of the brain, which may be particularly useful in perimenopausal women. Its estrogenic effect on bone also may be helpful in this age group.

\section{ORMELOXIFENE}

\section{STRUCTURE}

Ormeloxifene is non-hormonal and non-steroidal and belongs to the Benzopyran group. ${ }^{13}$ It is a third generation SERM.

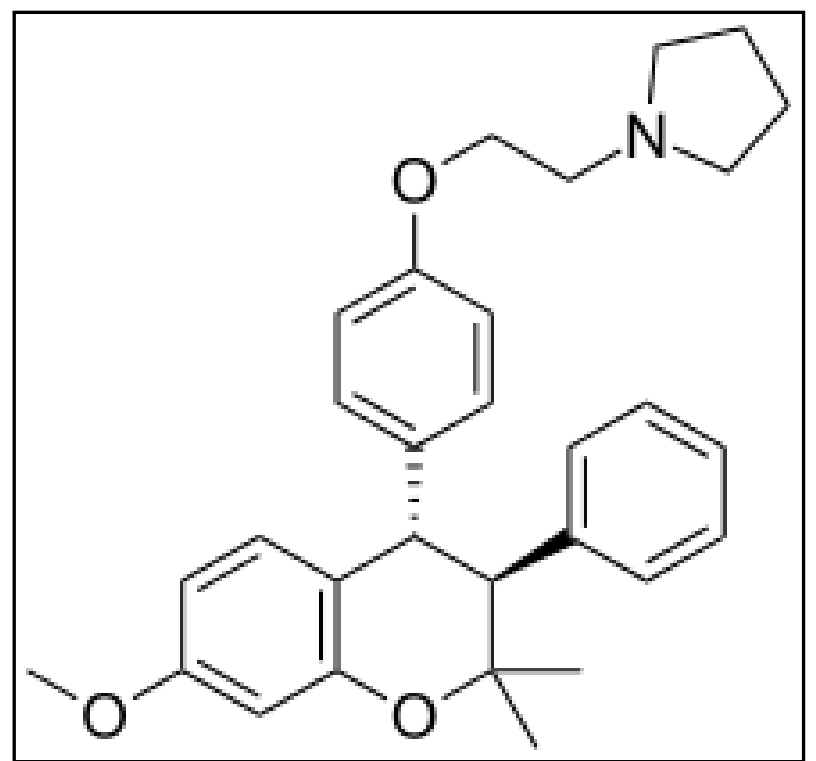

Systematic (IUPAC) name. 1-[2-[4-[(3S, 4R)-7-methoxy-2,2dimethyl-3-phenyl-chroman-4-yl] phenoxy] ethyl] pyrrolidine.

\section{Pharmacokinetics}

It exerts a contraceptive effect and normalise bleeding from uterus by regularising expression of estrogen receptors. It is well absorbed by gastrointestinal tract. Peak serum levels are achieved in $4 \mathrm{hrs}$. Its half-life is approximately $170 \mathrm{hrs}$. and hence can be taken once or twice per week. It is metabolised by the liver. Its concentration in uterus is next only to liver. ${ }^{14}$

Contraindications are hepatic dysfunction, hypersensitivity, pregnancy and lactation.

\section{MATERIAL AND METHODS}

This is a prospective study taken up at a teaching hospital, CKM Government Maternity Hospital attached to Kakatiya Medical College, Warangal.

Recruitment of the cases for study was done from September 2012 to June 2014. Women with history of menorrhagia attending gynaecological OPD were evaluated and those diagnosed as DUB were considered for the study.

All cases were subjected to routine investigations after taking detailed history and ultrasound was done to exclude any pathology. TVS was done to assess Endometrial Thickness (ET) in all cases. Endometrial aspiration was done if ET was $8 \mathrm{~mm}$ or more, between 8 to 10 days of the cycle, if cycles were regular. In some, $\mathrm{D}$ and $\mathrm{C}$ was done in an attempt to control an episode of menorrhagia and histopathology obtained to exclude atypia or complex hyperplasia.

Approval from the institutional ethical committee was taken for the study.

\section{Inclusion Criteria}

- Women of age 30 to 50 years with history of menorrhagia.

- With or without history of previous treatment for menorrhagia.

\section{Exclusion Criteria}

- Presence of pelvic pathology.

- $\quad$ Fibroids.

- Adenomyosis.

- Endometriosis.

- PID

- $\quad$ Adnexal masses/ovarian cysts $>5 \mathrm{cms}$.

- Endometrial biopsy showing atypia or malignancy.

- $\quad$ Post-menopausal bleeding.

- Severe anemia.

- Immune deficiency.

- Liver dysfunction.

- Renal impairment.

- Blood dyscrasias.

- Cervical pathology with CIN 3, atypia or malignancy.

- $\quad$ Cardiac disease and CNS disorders.

\section{Dosage Schedule}

The patients selected for study were divided into two groups.

Group A-Patients in this group received the standard dose as used in the previous studies, i.e. $60 \mathrm{mg}$ Ormeloxifene twice a week for 3 months followed by $60 \mathrm{mg}$ Ormeloxifene once a week for 3 months.

Group B-Patients in this group received reduced dose as follows-Ormeloxifene 30mg was given twice a week for the total 6 months of the study period.

No hormones or haemostatic agent was used during the study period.

Age, parity and BMI was noted and compared for both groups. All participants were taught how to fill up the PBAC Chart. It was also ensured that all used similar sanitary pads to ensure judicious comparison. PBAC score (Table 1) of more 
than 100 was taken as menorrhagia. Two pre-treatment baseline cycles were taken for comparing and assessing the effectiveness of the treatment and PBAC Scoring. ${ }^{15}$ was done in all cases. PBAC scores were calculated again at intervals of 1 month, 3 months and 6 months and the results compared for both groups.

ET (Endometrial thickness) was assessed by TVS for all the cases before starting Ormeloxifene and at the end of 6 months after starting treatment. (Table2) When patients had regular cycles, ET was done between 8 to 10 days of the last cycle or else at the end of the study period, i.e. 6 months after starting treatment and compared to the pre-treatment values (Table 5).

Haemoglobin levels were done as part of complete blood picture for all cases before including in the study and cases of severe anaemia $<7 \mathrm{G} / \mathrm{dL}$ were withheld from the study. Haemoglobin levels were again repeated at the end of 6 months. All patients with less than $10 \mathrm{gms}$ haemoglobin were given $60 \mathrm{mg}$ elemental iron and $500 \mathrm{mg}$ calcium and dietary advice for protein intake. Side effects were noted by taking detailed history and ultrasound scan at followup visits. Number of cases according to PBAC Score were estimated at 1 month, 3 months and at the end of 6 months study (Table 2, 3 and Fig. 2). Number of cases with $<100$ PBAC score were compared at the end of 6 months study for both groups.

Mean and SD was calculated for PBAC scores of both groups pre-treatment and again at the end of 1 month, 3 months and 6 months study and results compared. The periodic mean PBAC in two groups were compared using paired 't-test.' The mean ET in both groups also was compared using 't-test.' The p values were calculated to know if there was statistically significant difference in the efficacy of the dose schedules for Group A and Group B. The difference between the two groups with $\mathrm{p}$ value $<0.05$ was defined as statistically significant.

\section{RESULTS}

Out of 430 women with menorrhagia evaluated, 240 were eligible for the study. Only 160 women consented to participate, out of which half of the patients were given the standard dose of Ormeloxifene that is 60mg twice a week for 3 months and $60 \mathrm{mg}$ once a week for 3 months (Group A). Half of the patients were given reduced dose of Ormeloxifene that is $30 \mathrm{mg}$ twice a week for all 6 months (Group B); 54 women from each group who completed the 6 months treatment and came regularly for followup were included in the study. The average age and parity of women recruited was comparable in both groups. Age was 39.2 (range 30 to 50 yrs.) and parity was 2.3 (Range 1 to 5).

Number of patients were compared depending on PBAC Scoring, (Table 2). At the end of third month 42 (75.92\%) patients in group A had scores less than 100 compared to 41 (75.92\%) patients in group B (Table 3 ). This shows further comparable reduction in amount of blood loss in both regimes.

At the end of six months, 46 pts. (85.18\%) had scores less than 100 in group A compared to 47 (87\%) pts. in group B. (Fig. 1, Table 4). There was no significant difference between the two groups regarding efficacy.

Mean PBAC score in group A before treatment is 322 (126-450) and the mean PBAC score in group B is 325 (124482). The majority of patients (50\%) in group $A$ and $51 \%$ of patients in group B scored between 275 and 400 before treatment. Mean PBAC score in group A and mean PBAC score in group $B$ before and after treatment for 1 month, 3 months and 6 months are depicted in Fig. 2. There was significant difference between the pre-and post-treatment mean PBAC scores in both groups (Table 5).

The mean PBAC scores at the end of 6 months study in group A were 43.04, whereas in group B it was 40.07 with ( $p$ value $=0.3$ ) indicating that there is no statistically significant difference with regard to reduction of PBAC scores between group A and group B (Table 6). Endometrial thickness showed reduction in most patients in group $B$, but in group $A, 27 \%$ cases showed endometrial thickness of more than $10 \mathrm{~mm}$ after 6 months treatment (Fig. 3, Table 7).

While 6 cases in group A showed ovarian cysts of 5 to $6 \mathrm{cms}$, only 1 case in group B had an ovarian cyst at the end of 6 months study period (Fig. 4). Amenorrhoea occurred in 21 cases $(38.9 \%)$ of group A and 18 cases $(33.3 \%)$ of group B, which was helpful in improving the haemoglobin levels. Patients were initially counselled regarding this beneficial side effect and it was welcome relief for most patients. Haemoglobin concentration $(\mathrm{g} / \mathrm{dL})$ improved significantly in both groups with a mean increase of 2.42 in group A and 2.36 in group B. Side effects observed in our study are shown in Table 8.

\section{DISCUSSION}

Surgery is not the answer for young patients who still have not finished reproduction. Unfortunately, now in the modern times, planning pregnancy is unduly delayed by working women due to change of priorities. Hence, ideal medical therapy for those women with DUB is the need of the hour in such situations. ${ }^{16}$ Contraceptive action of Ormeloxifene is another advantage in these women who are not planning pregnancy yet. 17,18

In perimenopausal women, again, medical therapy should be the principle line of treatment. Surgery should not be the first preference in this age group because of the morbidity and mortality associated. ${ }^{19}$ Many times medical management for a limited period or repeated courses of medical therapy could avoid surgery in many women as they attain menopause during or sometime after medical treatment.16,14

The present comparative study shows that the mean PBAC scores at the end of 6 months study period reduced from 322.13 to 43.04 and from 325.04 to 40.07 in group A and group $\mathrm{B}$ respectively. The reduction of menorrhagia as reflected by the reduction of mean PBAC scores as compared to the pretreatment PBAC scores is $86.64 \%$ and $87.69 \%$ in groups A and $B$ respectively.

The difference in reduction of menorrhagia is not statistically significant $(p=0.33)$. The response in both groups shows almost same efficacy. Initially after one month, only 62 $64 \%$ of people responded, by the end of 3 months nearly $75 \%$ of the patients and later $85-87 \%$ showed PABC scores of $<100$ in both groups. In group A at the end of 6 months, ET $<5 \mathrm{~mm}$ in 16 pts. in group A compared to 25 pts. in group B. The mean of ET in group A is 2.8, whereas it is 2.1 in group B. The difference in endometrial thickness in both the groups is statistically significant $(\mathrm{P}=0.03)$.

Side effects of group A are comparable with the pilot study done in 2009 study (5) Group B showed less side effects (Table 8). This indicates that reduced dosage schedule used for 
group B patients has a definite advantage of minimal side effects while not compromising with the efficacy.

Amenorrhoea was noted in 21 (Gr A) and 18 (Gr B) patients at the end of 6 months is comparable to other studies done. (Biswas et al. 17.64\% of pts. showed amenorrhoea, Kripalini et al. 46\%), Biswas et al. noted that most of the pts. who attained amenorrhoea were in perimenopausal age group. No such observation was seen in our study.

The beneficial side effects due to its anti-estrogenic effect on the breast and mild agonistic effect on bone, vagina and serum lipids make Ormeloxifene more preferable for treatment of menorrhagia. Studies were and are being done regarding the anti-breast cancer action of Ormeloxifene. ${ }^{20,21}$ It also has beneficial effect in patients with fibroadenomas and mastalgia.

The results of the present study with regard to reduction of menorrhagia when compared to other studies (Table 9) show similar outcomes in most of the studies.

When compared to the other SERMS available, Ormeloxifene does not have the disadvantage of estrogenic action on endometrium like Tamoxifen and the anti-estrogenic effect on vagina of Raloxifene.

Recent evidence indicates that each SERM has a unique array of clinical actions on all tissues having estrogen receptors. Therefore, any particular SERM has to be evaluated individually and conclusions drawn through appropriate clinical trials. ${ }^{22}$

Control of menorrhagia with Ormeloxifene is also showing good success in cases with fibroids and adenomyosis and further studies will prove its role in those conditions.

\section{CONCLUSION AND RECOMMENDATIONS}

This study shows that the reduced dose schedule of ormeloxifene can be routinely used for DUB with same effectiveness and negligible side effects. Our study involved only limited number of patients and only for 6 months. Further studies for much longer periods could assure in future regarding the safety of this drug when used long term or for its repeated usage when menorrhagia recurs.

It is our sincere hope that in future an ideal SERM may be ormeloxifene would become the first line of treatment for menorrhagia.

Effective medical therapy has the potential to reduce surgical procedures like hysterectomy and endometrial ablation. ${ }^{23}$ Safe medical management of DUB could then be community based with referrals reduced to those with some underlying pathology. ${ }^{24}$

Future studies to show the benefits and safety of combination of Ormeloxifene with other modalities, viz. progestins, antifibrinolytics or non-steroidal antiinflammatory drugs for initial rapid control when patients present with severe menorrhagia and severe anaemia may make surgery a rare indication for DUB in future.

\begin{tabular}{|c|c|c|}
\hline \multirow{3}{*}{ Pads } & 1 point & For each lightly stained \\
\cline { 2 - 3 } & 5 points & For each moderately stained \\
\cline { 2 - 3 } Clots & 20 points & For each completely stained \\
\cline { 2 - 3 } & 1 point & $\begin{array}{c}\text { For each small clot (less than a } \\
\text { rupee coin) }\end{array}$ \\
\cline { 2 - 3 } & 5 point & $\begin{array}{c}\text { For each large clot (more than a } \\
\text { rupee coin) }\end{array}$ \\
\cline { 2 - 3 } & 5 point & For each episode of flooding \\
\hline \multicolumn{2}{|c|}{ Table 1: PBAC Score } \\
\hline
\end{tabular}

\begin{tabular}{|c|c|c|}
\hline $\begin{array}{c}\text { PBAC } \\
\text { Score }\end{array}$ & Group A n (\%) & Group B n (\%) \\
\hline $\begin{array}{c}100- \\
200\end{array}$ & $9(16.36 \%)$ & $11(20.37 \%)$ \\
\hline $\begin{array}{c}200- \\
300\end{array}$ & $27(50 \%)$ & $24(44.44 \%)$ \\
\hline$>300$ & $18(33.34 \%)$ & $19(35.185 \%)$ \\
\hline TOTAL & $\mathbf{5 4}$ & $\mathbf{5 4}$ \\
\hline \multicolumn{2}{|c|}{ Table 2: PBAC Scores as per $\mathbf{n}(\%)$ Pre-Treatment } \\
\hline
\end{tabular}

\begin{tabular}{|c|c|c|c|c|}
\hline \multirow{2}{*}{$\begin{array}{c}\text { PBAC } \\
\text { Score }\end{array}$} & $\begin{array}{c}\text { Ar A n } \\
(\%)\end{array}$ & $\begin{array}{c}\text { Gr B n } \\
(\%)\end{array}$ & $\begin{array}{c}\text { Gr A n } \\
(\%)\end{array}$ & $\begin{array}{c}\text { Gr B n } \\
(\%)\end{array}$ \\
\cline { 2 - 5 }$<100$ & 34 & 35 & 42 & 41 \\
& $(62.96 \%)$ & $(64.81 \%)$ & $(75.92 \%)$ & $(75.92 \%)$ \\
\hline 100 To & 14 & 12 & 8 & 7 \\
150 & $(25.92 \%)$ & $(22.23 \%)$ & $(14.82 \%)$ & $(12.96 \%)$ \\
\hline$>150$ & 6 & 7 & 4 & 6 \\
& $(11.12 \%)$ & $(12.96 \%)$ & $(7.4 \%)$ & $(11.12 \%)$ \\
\hline TOTAL & $\mathbf{5 4}$ & $\mathbf{5 4}$ & $\mathbf{5 4}$ & $\mathbf{5 4}$ \\
\hline \multicolumn{5}{|c|}{ Table 3: PBAC Scores n (\%) at follow-up } \\
during study period
\end{tabular}

\begin{tabular}{|c|c|c|}
\hline PBAC Score & Group A n (\%) & Group B n (\%) \\
\hline$<100$ & $46(85.18 \%)$ & $47(87.03 \%)$ \\
\hline 100 T0 150 & $5(9.25 \%)$ & $3(5.55 \%)$ \\
\hline$>150$ & $3(5.55 \%)$ & $4(7.41 \%)$ \\
\hline TOTAL & $\mathbf{5 4}$ & $\mathbf{5 4}$ \\
\hline \multicolumn{2}{|c|}{ Table 4: PBAC Scores n (\%) at the end of 6 months } \\
\hline
\end{tabular}

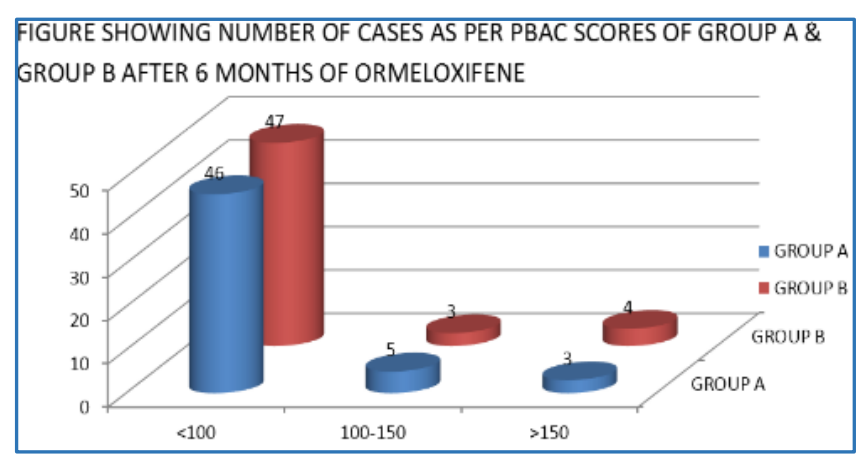

Figure 1

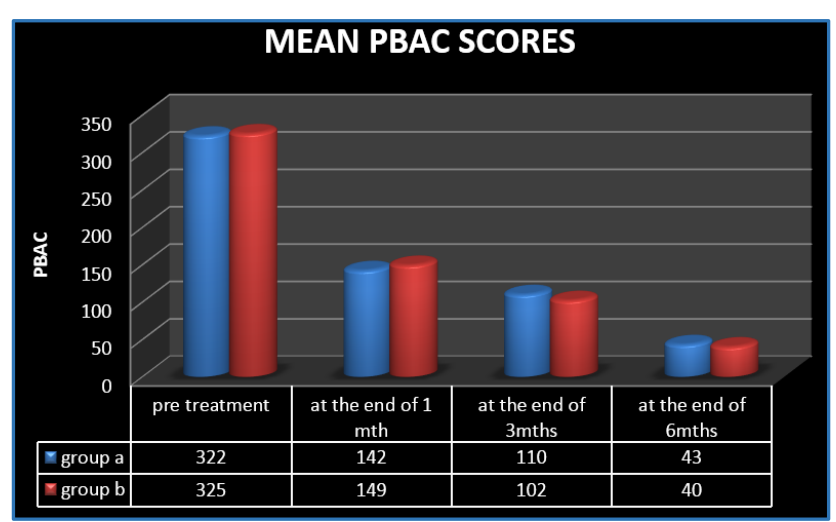

Figure. 2

\begin{tabular}{|c|c|c|c|c|}
\hline Group & $\begin{array}{c}\text { Mean PBAC } \\
\text { Score--Pre } \\
\text { treatment }\end{array}$ & $\begin{array}{c}\text { Mean PBAC } \\
\text { Score at end } \\
\text { of } 6 \text { mths } \\
\text { study }\end{array}$ & T value & P value \\
\hline $\begin{array}{c}\text { GROUP } \\
\text { A }\end{array}$ & 322.13 & 43.04 & 20.808 & $<0.001$ \\
\hline GROUP B & 325.04 & 40.07 & 20.580 & $<0.001$ \\
\hline \multicolumn{5}{|c|}{ Table 5: Comparison of Pre \& Post Treatment } \\
Values at 6 Months \\
\hline
\end{tabular}




\begin{tabular}{|c|c|c|c|}
\hline GROUP & Mean PBAC Score & T value & P value \\
\hline GROUP A & 43.04 & \multirow{2}{*}{0.416} & \multirow{2}{*}{0.33} \\
\cline { 1 - 2 } GROUP B & 40.07 & & \\
\cline { 1 - 2 } $\begin{array}{r}\text { Table 6: Comparison of mean PBAC score } \\
\text { of Gr A with Gr B at the end of 6 Mths }\end{array}$ \\
\hline
\end{tabular}

\begin{tabular}{|c|c|c|c|c|c|}
\hline ET(mm) & Gr A & Gr B & ET(mm) & Group A & Group B \\
\hline $0-5$ & 8 & 6 & $0-5$ & 16 & 25 \\
\hline $6-10$ & 27 & 28 & $6-10$ & 23 & 24 \\
\hline$>10$ & 19 & 20 & $>10$ & 15 & 5 \\
\hline TOTAL & $\mathbf{5 4}$ & $\mathbf{5 4}$ & TOTAL & $\mathbf{5 4}$ & $\mathbf{5 4}$ \\
\hline \multicolumn{6}{|c|}{$\begin{array}{c}\text { Table 7: Endometrial thickness before } \\
\text { and after treatment (6 Mths) }\end{array}$} \\
\hline
\end{tabular}

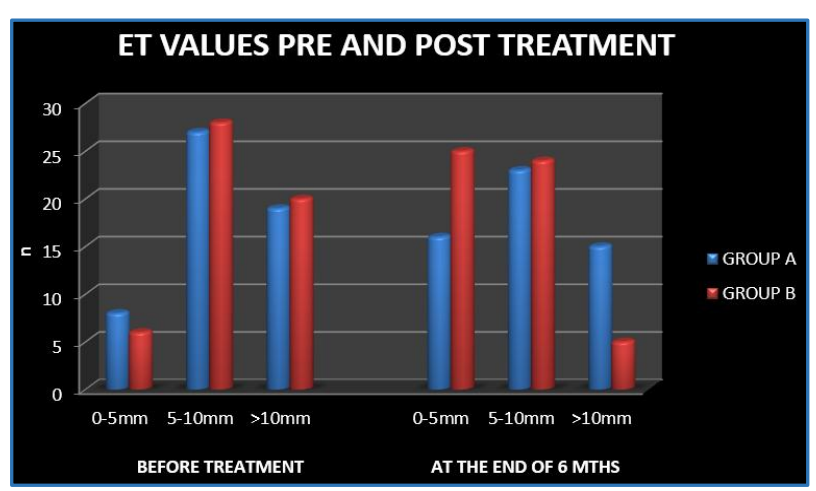

Figure. 3

\begin{tabular}{|c|c|}
\hline GASTROINTESTINAL 6 & 3 \\
\hline WEIGHT GAIN 4 & 2 \\
\hline HEADACHE 7 & 3 \\
\hline OVARIAN CYSTS 6 & 1 \\
\hline AMENORRHOEA 20 & 18 \\
\hline Table 8: Side Effects : Group A & Group B \\
\hline
\end{tabular}

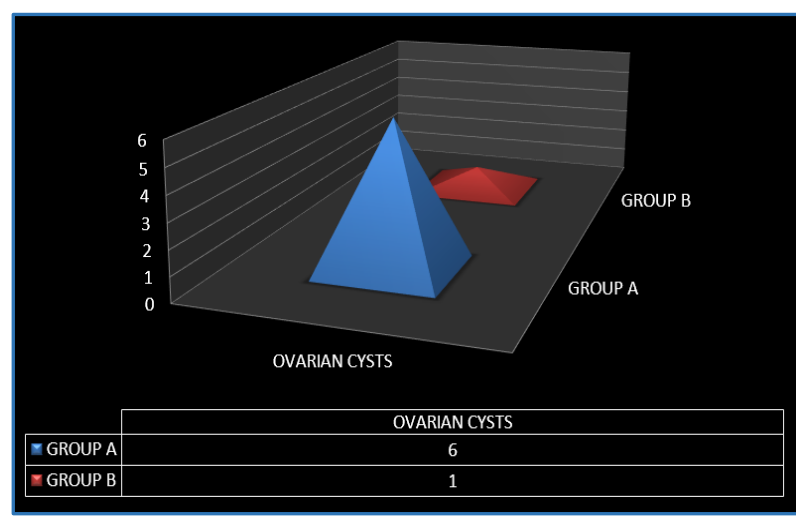

Figure 4: Ovarian cysts detected at the end of 6 months

\begin{tabular}{|c|c|c|c|}
\hline STUDY & DURATION & DOSAGE & $\begin{array}{l}\text { REDUCTION IN MEAN } \\
\text { PBAC SCORE \% }\end{array}$ \\
\hline BISWAS SL, et al. (2004) & 6 mths & $\begin{array}{l}60 \mathrm{mg} \text { twice wkly for } 3 \mathrm{mths} \mathrm{f} / \mathrm{b} \\
60 \mathrm{mg} \text { once a wk for } 3 \mathrm{mths}\end{array}$ & $85.7 \%$ \\
\hline J. SHRAVAGE et al. (2009) & 6 mths & $\begin{array}{l}60 \mathrm{mg} \text { twice wkly for } 3 \mathrm{mths} \mathrm{f} / \mathrm{b} \\
60 \mathrm{mg} \text { once a wk for } 3 \mathrm{mths}\end{array}$ & $85.7 \%$ \\
\hline $\begin{array}{c}\text { Phase III drug trial India } \\
\text { (unpublished product monograph) by } \\
\text { Torrent Pharma }\end{array}$ & $6 \mathrm{mths}$ & $\begin{array}{l}60 \mathrm{mg} \text { twice wkly for } 3 \mathrm{mths} \mathrm{f} / \mathrm{b} \\
60 \mathrm{mg} \text { once a wk for } 3 \mathrm{mths}\end{array}$ & $87.8 \%$ \\
\hline KRIPALINI A. et al. (2009) & $4 \mathrm{mths}$ & $\begin{array}{l}60 \mathrm{mg} \text { twice wkly for } 3 \mathrm{mths} \mathrm{f} / \mathrm{b} \\
60 \mathrm{mg} \text { once a wk for } 1 \mathrm{mth}\end{array}$ & $97.7 \%$ \\
\hline PRASAD S. et al. (2000) & $6 \mathrm{mths}$ & $\begin{array}{c}60 \mathrm{mg} \text { twice wkly for } 3 \mathrm{mths} \mathrm{f} / \mathrm{b} \\
60 \mathrm{mg} \text { once a wk for } 3 \mathrm{mths}\end{array}$ & $80-87.7 \%$ \\
\hline N. AGARWAL et al. (2013) & $6 \mathrm{mths}$ & $\begin{array}{l}60 \mathrm{mg} \text { twice wkly for } 3 \mathrm{mths} \mathrm{f} / \mathrm{b} \\
60 \mathrm{mg} \text { once a wk for } 3 \mathrm{mths}\end{array}$ & $90.4 \%$ \\
\hline Our study Group A & $6 \mathrm{mths}$ & $\begin{array}{l}60 \mathrm{mg} \text { twice wkly for } 3 \mathrm{mths} \mathrm{f} / \mathrm{b} \\
60 \mathrm{mg} \text { once a wk for } 3 \mathrm{mths}\end{array}$ & $86.64 \%$ \\
\hline Our study Group B & $6 \mathrm{mths}$ & $30 \mathrm{mg}$ twice wkly for $6 \mathrm{mths}$ & $87.69 \%$ \\
\hline \multicolumn{4}{|c|}{ Table 9: Comparison with other studies where standard dose of ormeloxifene was used for 6 months } \\
\hline
\end{tabular}

\begin{tabular}{|c|c|}
\hline BISWAS et al. & $87.5 \%$ \\
\hline SHRAVAGE et al. & No significant reduction \\
\hline N. AGARWAL et al. & Decrease in mean ET 3.08 \\
\hline DHANUNJAY B et al. & Decrease in mean ET by 3.47 \\
\hline TORRENT PHARMA & Decrease in mean ET by 2.1 \\
\hline OUR STUDY & Dable 10 : ET Reduction as shown in other study groups \\
\hline \multicolumn{2}{|r}{} \\
\hline
\end{tabular}

\section{REFERENCES}

1. Oehler MK, Rees MC. Mennorrhagia: an update. Acta Obstet Gynecol Scand 2003;82(5):405-22. [PubMed]

2. Dadhich S, Agarwal S, Soni M, et al. Role of ormeloxifene in medical management of dysfunctional uterine bleeding. Asian J Obstet Gynaecol Practice 2012;6:28-31.
3. Lethoby A, Augood C, Duckitt K, et al. Non-steroidal antiinflammatory drugs for heavy menstrual bleeding. Cochrane database of systematic reviews 2007 (Issue 4). Art No CD00400: DOI: 10.1002/14651858 Pub 2.

4. Prasad S Centchroman. A novel drug for DUB J Obstet Gynecol India 2000;50:77-79. 
5. Kriplani A, Kulshrestha V, Agarwal N. Efficacy and safety ormeloxifene in the management of menorrhagia: a pilot study. The Journal of Obstetrics and Gynecol Research 2009;35(4):746-52.

6. Fraser IS, Jansen RPS, Lobo RA, et al. Oestrogens and progestogens in clinical practice, Chapter 35 "Dysfunctional Uterine Bleeding." Church II Living Stone Publication 1998;419-37.

7. Hatasaka H. The evaluation of abnormal uterine bleeding. Clinical Obstetrics and Gynaecology 2005;48(2):382-97.

8. Irvine GA, Cameron IT. The medical management of dysfunctional uterine bleeding. Baillieres Best Pract Res Clin Obstet Gynaecol 1999;13(2):189-202. [PubMed]

9. Shravage J, Mekhala D, Bellad MB, et al. Ormeloxifene versus Medroxyprogesterone Acetate (MPA) in the treatment of dysfunctional uterine bleeding: a doubleblind randomized controlled trial. JSAFOG 2011;3:21-4.

10. Lethaby A, Irvine GA, Cameron IT. Cyclical progestogens for heavy menstrual bleeding. Cochrane database of systematic reviews 2008 (Issue 1). Art No CD001016. DOI: 10.1002/14651858. cd001016. pub.

11. Biswas SC, Saha SK, Bag TS, et al. Ormeloxifene: a selective estrogen receptor modulator for treatment of dysfunctional menorrhagia. J Obstet Gynecol Ind 2004;54(1):56-59.

12. Wendy Shelly, Michael W Draper, Venkatesh Krishnan, et al. Selective oestrogen receptor modulators: update on recent clinical findings. Obstetrical and Gynaecological Survey Mar 2008;63(3):163-81.

13. Steven R Goldstein, Suresh Siddhanthi, et al. Human reproduction update 2000, Volume 6, No 3, pp. 212-224.

14. Living Stone M, Eraser IS. Mechanism of abnormal uterine bleeding. Human reprod update 2002;8(1):6067.

15. Higham JM, Obrien PMS, Shaw RW. Assessment of menstrual blood loss using a pictorial chart. British Journal of Obstetrics and Gynaecology 1990;97:734-39.
16. Studd J. Progress in Obstetrics and Gynaecology, Chapter 17. "Abnormal uterine bleeding: diagnosis and medical management." Churchill Livingstone 2003;12:309-27.

17. Malhotra KP, Sherpa M, Bhatia A. Eur J Contracept and Reprod Health Care. 2011 Oct; 16(5):403-6. Doi:10.3109/13625187.2011.595851. Epub 2011 Jul 21.

18. Lal J (April 2010). "Clinical pharmacokinetics and interaction of centchroman--a mini review." Contraception 81(4):275-80. doi:10.1016/j. contraception. 2009.11.007. PMID 20227542.

19. Biswas SC, Saha SK, Bag TS, et al. Ormeloxifene: a selective estrogen receptor modulator for treatment of dysfunctional menorrhagia. J Obstet Gynecol Ind 2004;54(1):56-59.

20. Kumar GR, Rituraj K, Hemant BK, et al. The in-vitro anticancer breast activity of ormeloxifene is mediated via the induction of apoptosis and autophagy. 37th Annual Conference of the Endocrine Society of India. $30 \mathrm{Nov}-2$ Dec, 2007 Abstract p35.

21. Ranjan Manisha N, Srivastava Vishal, Sharma Swasti, et al. "Centchroman induces the G0/G1 arrest and the caspase-dependent apoptosis which involves the mitochondrial membrane depolarization in the MCF-7 and the MDA MB-231 human breast cancer cells." Life Sciences 2008;82:577-90.

22. Shelly W, Draper MW, Krishnan V, et al. The selective estrogen receptor modulators: an update on the recent clinical findings. Obstet Gynecol Surv 2008;63(3):16381. [PubMed]

23. Nelson AL, Teal SB. Medical therapies for chronic menorrhagia. Obstet Gynecol Surv 2007;62(4):27281. [PubMed]

24. Porteous A, Prentice A. The medical management of dysfunctional uterine bleeding. Reviews in Gynaecological Practice 2003;3(2):81-84. 